\title{
“Ev Dekorasyon” Dergisi (1976-82) Üzerinden Konutlardaki İç Mekân Özelliklerinin İncelenmesi
}

Tuba Bülbül Bahtiyar

Doç. Dr. Esra Yaldız

Özet

Yazılı basın olarak adlandırılan gazeteler ve dergiler içinde bulundukları dönem ve toplumsal koşullar ile doğrudan ilişkili metinler ve görseller içeren kitle haberleşme araçlarıdır. Hızla değişen ve etkileşen toplumdaki beğenileri, ekonomik ve kültürel değerleri, sosyokültürel yapıyı, alıskanlıkları vs. gibi durumları bu metinler ve görseller üzerinden okumak ve değerlendirmek mümkündür. Bu kapsamda ele alınan çalşmada, Türkiye'de 1970'lerden sonra kapitalist düzenin getirisi olarak kırsaldan kente göç sonucu hızla artan apartmanlaşmayla birlikte oluşan konut tipolojisinde yer alan mekanların özellikleri 1976-82 yılları arasında yayıllanmış Türkiye'nin ilk dekorasyon dergilerinden "Ev Dekorasyon" dergisinde yer alan örnekler üzerinden değerlendirilerek dönemin konutlar hakkında genel bir bakış açışı oluşturulmaya çalışılmış; dergide yer alan görseller ve metinler üzerinden dönemin konutlarındaki iç mekân düzenlemelerinin ve yaşam tarzlarııı sunumunun analiz edilmesi hedeflenmiştir. Modernleșme yolunda ilerleyen topluma yașam tarzlarının artık evler, mobilyalar ve dekorasyon ürünleri ile tamamlandığı vurgusunda olan bu dergi üzerinden yapılan analizler sonucunda dekorasyon anlayışlarının dönemin toplumsal, ekonomik ve sosyokültürel değerleri ile paralellik gösterdiği görülmüştür.

Anahtar Sözcükler: Apartman, Ev Dekorasyon Dergisi, iç Mekân, Konut, Mobilya

ASSESSMENT OF THE INTERIOR PROPERTIES OF HOUSES THROUGH THE JOURNAL ENTITLED “EV DEKORASYON” (1976-82)

\section{Abstract}

The newspaper sand journals named as printed media include texts and visuals that are directly related to the periods when they are published and to the social conditions of these periods. One can assess the approved acts or concepts, financial and cultural values, socio-cultural structure or habits of a society that rapidly acts or concepts, financial and cultural values, socio-cultural structure or habits of a society that rapidly changes and interacts with other societies through these texts and visuals. Accordingly, this study evaluated the
spatial characteristics of houses within the housing typology that was formed with the rapidly-growing trend of spatial characteristics of houses within the housing typology that was formed with the rapidly-growing trend of "apartmentization" as a result of migration from rural to urban areas triggered by the capitalist system in Turkey
after 1970s through the examples within the journal entitled "Ev Dekorasyon" - one of the first decoration-based journals published between 1976 and 1982 in Turkey. In addition, it aimed to create a general perspective toward the houses of the era and to analyze the presentation of interior properties of lifestyles within the houses of the era through the texts and visuals in the afore-noted journal. The results of the analyses regarding this journal which reported that lifestyles were then completed with houses, furniture and decorative products in the societies aiming to become modernized showed that decoration-related conceptions have been in parallel with the social, economic and socio-cultural values of their eras.

Keywords: Apartment, Ev Dekorasyon Journal, Interior, Housing, Furniture 


\section{Giriş}

Kapitalizm, bireyleri iş haricindeki zamanlarında tüketime yönlendiren bir üretim ve tüketim modelidir (Galbraith, 2009; Işık ve Duman, 2012; Saral Güneş ve Kükrer Aydın, 2016: 221). Kapitalizmin temel amacı ise mevcut aşırı üretimin tüketilmesini sağlayarak tüketimin kalıcı hale gelebilmesi için onu bir kültür olarak benimsetmektir (Dağtaş ve Dağtaş, 2009: 51). Oluşan bu tüketim kültürü ise bireylerin gereksinimleri karşılamaktan öte gösteriş, sınıf atlama, belli bir gruba ait hissetme gibi simgesel değerler haline gelmiş (Dağtaş, 2003; Saral Güneş ve Kükrer Aydın, 2016), tüketim haz odaklı bir yaşam biçimine dönüşmüştür.

Kapitalist örgütlenme ve sermaye, mekânı bir araç olarak görmekte; kapitalist ekonominin gerekliliklerine, ihtiyaçlarına ve değişen şartlarına bağlı olarak mekânı yeniden değiştirmektedir. Mekânı oluşturan donatı elemanları ve iç mekân özellikleri de kapitalist üretim ilişkileri ve örgütlenme biçimlerinden etkilenmektedir.

Amerika'da 1950'lerde, Avrupa'da 1960'larda başlayan kapitalizm temelli tüketim patlaması Türkiye' de de 1970'li yıllarda benzer şekilde yaşanmıştır. 1970 öncesinde aynı üründen çok sayıda üretim odaklı "Fordizm" anlayışı 1970 'lerle beraber artık seri üretilen ürünlerden ziyade daha az sayıda ancak daha çok çeşit ürün üretilmesi şeklindeki yeni bir sisteme evrilmiştir. "Postfordizm" olarak adlandırılan bu sistemle birlikte hizmet sektörü gelişerek yeni orta sınıfın ortaya çıkmasına sebep olmuştur (Featherstone, 2005; Saral Güneş ve Kükrer Aydın, 2016:222). Bu yeni orta sınıf tüketim tercihleri ve yaşam biçimleri ile farklılaşma çabasına girmiştir.

Yaşam biçimleri yansıtmakta en iyi göstergelerden biri de bireylerin konutları ve iç mekân dekorasyonları olmuştur. Modern yaşam için en etkili yol olan konut mekanlarında değişen mobilyalar, yeni teknolojik ürünler ya da yeni malzemelerin uygulanması ile iç mekânlar artık yeni bir yüze kavuşmuşlardır. Batılı beğenilerin gelişimi ve modern yaşamauyum sağlama bireyler için sürekli merak konusu olmuş, bu durum eskiyi reddederek yeniye sahip olma arzusunu tetiklemiş̧ir (Kan Ülkü, 2018) Bu anlayışların değişmesi ve gelişmesinde görsel-işitsel basının (radyo, televizyon) ve yazılı basının (gazete, dergi vb) etkisi ise oldukça büyüktür. 1970'lerde görsel-işitsel basın olarak televizyonun konuta girmesi ve yazılı basın olarak dergicilik sektörünün gelişmesi ile birlikte evlerdeki dekorasyon giderek önemli hale gelmiştir.

Genel anlamda basının toplumları bilinçlendirmede ve yönlendirmede oldukça etkili olduğu ve toplumlar üzerinde yasama, yürütme ve yargıdan sonra "dördüncü güç" olduğu bilinmektedir (Yapar, 1999:163). Etkin kitle haberleşme aracı olan gazete, dergi, televizyon vb. insanların yakın çevrelerinde yaşanan değişimden haberdar olmalarını sağlamaktadır. Yazılı basının bir türü olan dergicilik ise Batı'da 17. yüzyılda ortaya çıkarken Türkiye'ye gelişinde matbaanın geç gelmesi sebebiyle iki yüzyıllık gecikme ile olmuştur. Ancak ilk gazetenin yayınlanmasından (1831) kısa süre sonra dergiler de yaygınlaşmaya başlamıştır (Gönenç, 2007:64).Dünya'da dergicilik sektöründe başta gelen ülke Amerika iken Avrupa'da Fransa ve Finlandiya'dır (Yapar, 1999). Türkiye de dergicilik anlamında Amerika ve Fransa'dan etkilenmiştir.

Batı dünyasında dekorasyon üzerine yayınlanan dergilerin tarihi ise 19 . yüzyıla kadar inmektedir. 20. yüzyılın ortalarına gelindiğinde kapitalizmin tüketim toplumlarına dönüştürdüğü ülkelerden başta Amerika'da olmak üzere bu tip yayınların sayısı giderek artmıştır (Ceyhan, 2002:83). Bu yayınlarda hedef kitle genellikle modern şehirli kadınlardır. Ekonominin kadına tüketim noktasında biçtiği rolü en iyi şekilde yerine getirmeleri için gerekli faaliyet alanı olan (Mutlu, 2009:68) bu dergilerde ürün ve hizmet tanıtımlarının ötesinde bir tüketim kültürü yaratma çabası (Korkmaz, 2009; Saral Güneş ve Kükrer Aydın, 2016:221) bulunmaktadır. Türkiye'de 1976 yılında yayınlanmaya başlayan "Ev Dekorasyon" dergisi bu tür yayınların ilklerindendir (Ceyhan, 2002:83). Tüketim alışkanlıklarının hızla değişmesi üzerine artık yaşam tarzlarının evler, mobilyalar ve dekorasyon ürünleri ile belirlendiği, dekorasyon ürünlerinin toplumsal statü göstergesi olduğu vurgusunun yapıldığı bu dergi çalışma kapsamında analiz edilmiş ve değerlendirilmiştir.

\section{Kavramsal Çerçeve}

Türkiye Cumhuriyeti'nin kurulmasıyla beraber ülkenin toplumsal yapısı, kültür ve ekonomisi ile paralel bir şekilde, toplumun aydınlanması için yaşamın her alanında devrimler gerçekleştirilmiştir. Bu devrimler ile birlikte modernleşme hareketi şehir ölçeğinden mimariye ve konut iç mekân donatılarına kadar kendini hissettirmiştir (Bülbül Bahtiyar, 2019:42). Batılı yaşam biçimlerinin örnek alınması ve taklit edilmesi, iç mekânlarda birçok akım ve üslubun oluşmasına sebep olmuştur.

Türkiye'de batılı anlamda iç mekanlarda mobilya kullanımı Osmanlı döneminde Tanzimatfermanının ilanıyla başlamıştır. Cumhuriyetinilanından sonra I. Ulusal Mimarlık akımının da etkisi ve milliyetçilik duygusunun ağır basması sebebi ile Batıda moda olan mobilyaların geleneksel eşyalar ile birlikte kullanıldığı bir geçiş süreci yaşanmıştır. Bu yıllarda Art Nouveau akımı iç mekân düzenlemelerinde etkili olmuştur (Cananoğlu 2015: 65- 
72). 20. yüzyılın başıyla birlikte etkili olmaya başlayan modernizm, tüm mobilya geçmişi açısından bir dönüm noktası olarak değerlendirilmektedir. 1930 'lardan sonra, modern mobilya çizgisine yönelim olmuş; yeni mekân arayışları, eskimobilyalarınyerine modern mobilyaların gelmesinisağlamıştır (Durmuş, 2005: 77). Türk mobilyası da yalınlığı ve işlevselliği ön planda tutan bu yaklaşımdan yoğun şekilde etkilenmiştir (Ultav, Hasırcı, Atmaca ve Borvalı, 2015:483). 1940'lı yıllarda dönemin önde gelen mimarları, mimari tasarımlarında iç mekân düzenlemeleri ve modern mobilya kullanımın teşvik eden çalışmalar yapmışlardır. Türkiye'de modern mobilyanın yaygın kullanımı 1950'lerin sonu ve 1960'ların başına tarihlenmektedir (Cananoğlu 2015; 65). 1955 yılında açılan rasyonalist yalın mimari üslubu ile ön plana çıkan İstanbul Hilton Oteli; Türkiye'de modernist çizgiye sahip mobilyanın gelişimi ve yaygınlaşmasında önemli bir rol oynamıştır. Klasik batı üsluplarına ek olarak bu dönemlerde modern, Bauhaus ve bazı Art-Deco izleri taşıyan üslupta mobilyaların üretimi başlamıştır (Ceyhan, 2002:53).

1960 'Iı yıllar ile birlikte ev dekorasyonlarında geometrik modernizmden sonra organik ve heykelsi modern olarak da tanımlanabilecek ekspresyonizm akımının örnekleri verilmeye başlamıştır (Dinçay, 2014:1720). Bu yıllarda plastik, alüminyum gibi konut donanımında yeni kullanım bulan malzemelerden üretilmiş dekoratif aksesuarlar ve hızla değişen popüler kültür elemanları konut iç mekânını şekillendirmeye başlamıştır (Massey, 2008; Dinçay, 2014:23).1960'lar sonrası her türlü üsluba açı olunan bir dönem olmuş; kullanıcı ihtiyaç ve istekleri, çevresel faktörler, malzeme gibi etkenlere bağlı olan serbest biçimlenme anlayışı, farklı akım ve yaklaşımların birbirine üstünlük sağlamadığı, her türlü üsluba açık "çoğulculuk dönemi" başlamıştır(Ödekan, 1997; Ceyhan, 2002:65). Bu dönemdemobilya üreticileri "yarı klasik" adı altında, klasik batı mobilya üsluplarının asıl düzenlerine sadık kalınmadan ve karışık olarak kullanıldığı üslupta özensiz mobilyalar üretmeye başlamıştır (Güzer, 1999; Ceyhan, 2002:75). 1970'lerden sonra ise gelişen ve değişen yapı malzemeleri ve yapım teknolojileriyle farklı ve yeni biçim arayışlarının gündeme geldiği özellikle konut uygulamalarında postmodernist çizgiler hâkim olduğu bir süreç yaşanmıştır.

1980'li yıllarda, hızla yaşanan kentleşmeyle, teknolojik gelişimler sebebiyle Türkiye' de dışa açılımlar görülmeye başlamıştır. 1980'li yılların karakteristik özelliği tüketim kültürünün de etkisiyle evlerde lüks yaşam ve gösterişe duyulan ilgidir(Ceyhan, 2002:102). Bu yıllarda köyden kente göçün yaygınlaşmasıyla biçimlenen kentlerde mobilyayı bir statü sembolü olarak gören yeni bir kullanıcı kültürü gelişmiştir (Cananoğlu, 2015: 136). Orta sınıf üyesi bir aile gösterişçi tüketimini konutun dış mekânından ziyade konut içindeki donatıları ile gösterebilmiştir. Bu dönemde evlerin salonları adeta "saray odası" gibi döşenmiş, bu odalar sadece misafir ağırlanırken kullanılan mekânlar haline gelmiştir.

1980'lerin ortalarına kadar oymalı mobilyaların popülerliği azalmamıs fakat bundan sonraki dönemlerde mobilyalardaki oymalı işçilik giderek sadeleşmiştir (Ceyhan, 2002:102). Bu dönemde popülerliği artan anlayış ise konforun ve kullanışlılığın ön planda olduğu modern mobilyalardır (Kurtoğlu, 1986). Oturma mobilyalarında kullanılan malzeme ve üretim teknikleri ile ürünlerin ağırlıkları hafifletilmiştir. Mekânlar daha rahat ve sade olması sebebiyle evin düzeni de daha kolay sağlanmıştır (Artıkoğlu, 2006:162). Küreselleşme ekseninde gelişen 1980'ler sonrasında ise Türk halkının Batı kültürünü ana kültür gibi benimseme yolunda hızla ilerlediğ sürece girilmiştir. Yaşam tarzlarında ve beklentiler noktasında değişen toplumsal ve sosyal olgular, bireylerin Batı kültürüne entegre olma yolunda hızla aldığı yolun son basamaklarını teşkil etmiştir (Özakbaş, 2014:8). Tasarım tarihimizde iz bırakan tüm bu akımların topluma lanse edilmesinde ve benimsetilmesinde görsel ve yazılı basının rolü oldukça büyüktür.

\section{Materyal ve Yöntem}

\section{1. "Ev Dekorasyon" Dergisi ve İçeriği}

Ev Dekorasyon dergisi 1976 yılı eylül ayında ILBAS (İleri Basın Yayın Endüstri A.Ş) adına Türkiye'de gazetecilik ve dergicilik sektörünün önde gelen isimlerinden Haldun Simavi ${ }^{1 '}$ nin önderliğinde yayın hayatına başlayan Türkiye'nin ilk dekorasyon dergilerindenbiridir. 1982 yılına kadar aylık olarak yayınlanan dergide ünlü isimlerinkonutlarının dekorasyonlarına, yerli firmaların ürünlerinin tanıtımına, farklı dekorasyon fikirlerine, çeşitli mobilyalarla ilgili tarihçelere, derginin sonunda yer alan çarşı-pazar adlı bölümde görselleri ile birlikte verilen dekorasyon ürünlerinin satıldığı firmalara ve fiyatlarına yer verilmiştir.

Derginin her sayısında konutun farklı bir mekânı ele alınarak örnek dekorasyon fikirleri verilmiștir. Bu fikirlere ek olarak medya önündeki ünlü isimlerin, sanatçıların, iş adamlarının evleri örnek gösterilmiş (Görsel 1) ve sayfa aralarındaki reklamlar ile de tüketim desteklenmiştir.

'Haldun Simavi Hürriyet gazetesinin kurucusu Sedat Simavi'nin oğludur. Babasının 1953'te vefatından sonra gazetenin yönetimini 1968 yllına kadar sürdürmüştür. 1968 yllında kurduğu Günaydın gazetesinin yönetimi ise 1988 ylına dek sürdürmüştür. Günaydın Gazetesi bu yıllarda Türkiye'nin en çok satan, tirajı zaman I milyonu aşan gazetesi olmuştur. 


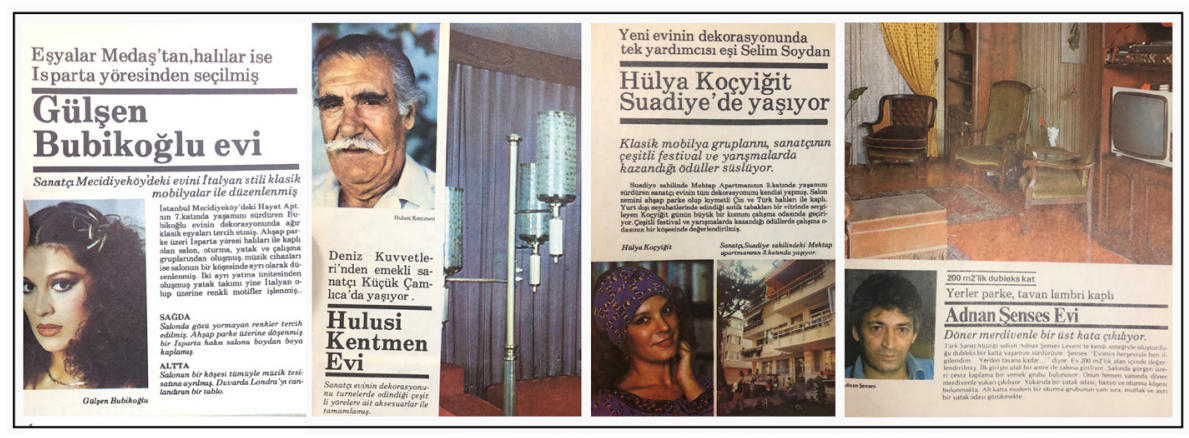

Görsel I. Ev Dekorasyon dergisinde ünlülerin evlerini tanıtan yazı başlıkları

\subsection{Araştırma Yöntemi}

Bu çalışmada "Ev Dekorasyon" dergisindeki iç mekân dekorasyonları ve mobilya reklamları dönemin etkili olan akım ve yönelimleri üzerinden incelenmiştir. Dergilerde yer alan görseller ve metinler üzerinden dönemin konutlarındaki birimlerin iç mekân anlayışlarının ve yaşam tarzlarının sunumunun analiz edilmesi hedeflenmektedir. 1970'lerde kapitalist düzenin getirisi kırsaldan kentlere doğru olan göçün etkisi sonucu hızla artan apartmanlaşmayla birlikte değişen konutların ortak hafızanın ürünleri olan mekanlar ve bu mekanların özellikleri, dergi üzerinden değerlendirilerek dönemin konutları hakkında genel bir bakış açışı oluşturulmaya çalışılacaktır

Çalışmanın kapsamına uygun olarak derginin 1976-1982 yılları arasında yayınlanan 73 sayısından 16 sayısı örneklem olarak seçilmiştir (Görsel 2). Örneklem belirlenirken çalışmanın amaçları doğrultusunda konutun farklı birimlerini ele alan sayılarının seçilmesine dikkat edilmiştir. Dergilerin analizinde nitel bir araştırma yöntemi kullanıldığından dolayı değerlendirme sonuçları genelleme kaygısı taşımamaktadır.

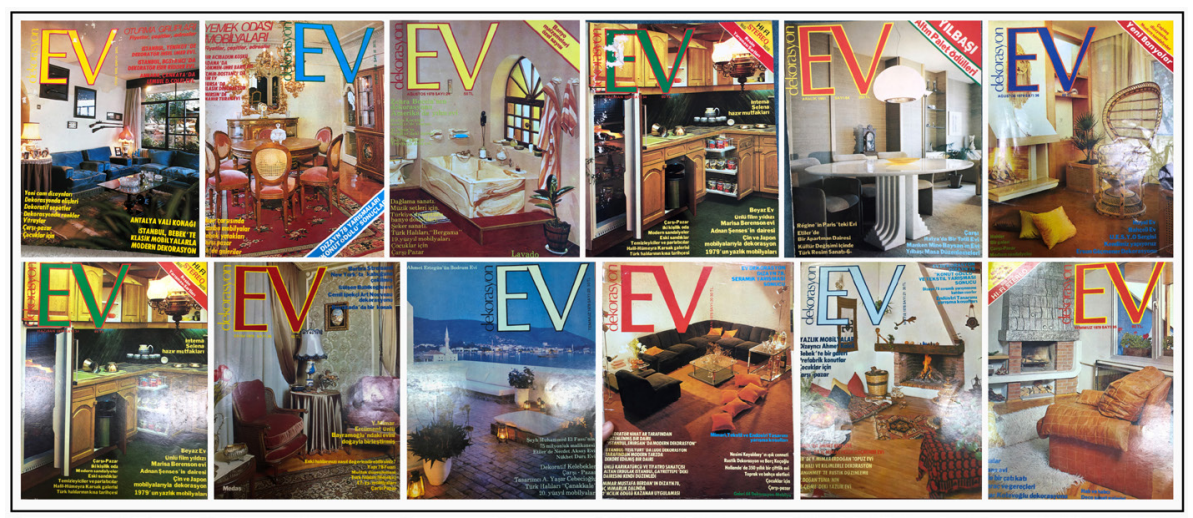

Görsel 2. Çalışma kapsamında incelenen Ev Dekorasyon dergisinin kapakları

\section{Bulgular ve Değerlendirme}

Bu bölümde dergide yer alan görseller ve metinler konutun iç mekanlarından salon, yemek odası/bölümü, oturma odası, ebeveyn yatak odası, çocuk odası, mutfak ve banyo şeklinde yedi başlığa ayrılarak analiz edilmiştir.

\subsection{Salon}

Salonlar evin kültür, prestij, zenginlik, misafirperverlik kavramlarıyla yüklü olan ve çevreye aileyi en iyi yansıtacak biçimde kaliteli ve gösterişli mobilyalarla döşeli (Artıkoğlu, 2006:110) mekanıdır. Cumhuriyet'in ilanından sonra 50 yıllık bir süreçte "konuklardan başkasına kapısının açılmadığı" (Keleş, 1993) bir salon anlayışı hâkimdir. Televizyonun evlere girmesi ile birlikte 1970'lerde bu "müze oda" durumu değişmeye başlasa da (Şalgamcıoğlu, 2013:45)oturma odası ve salon mekanlarının bir arada bulunduğu evlerde salonlar gösteriş yüklü mekanlar olmaya devam etmiştir.

Salonlardaki oturma gruplarını klasik veya modern tarz olarak ikiye ayırmak mümkündür. Klasik salonlarda Osmanlı saraylarında ve köşklerinde olduğu gibi mobilyalarda kullanılan kumasslar halı ve perdelerin kumașı ile uyumlu olarak (Demirarslan, 2018) tasarlanmıştır. Bu takım anlayışı zamanla bir dekorasyon modeli haline gelmiştir (Görsel 3).

Eklektik çizgiler taşıyan klasik takımlardaki mobilyalarda ince kesitler, oymalı ve kıvrımlı bacaklar, pençe şeklinde pabuçlar ve süslü yüzeyler kullanılmıştır. Ceviz kullanımının yanında yapay malzemelere de yer verilmiştir. Döşemelerinde goblen veya kadife kumaş kullanılmıştır. Bu tarz mobilyalar salonda köşelere yerleştirilen kumaş başlıklı ahşap ayaklı abajurlar ve mermer yüzeyli orta sehpalar ile gruplanmıştır (Görsel3). Salonlarda genellikle pencerenin önünde bir fiskos köşesi de bulunmaktadır. Fiskos köşesinde ortada yuvarlak bir masaya iki sandalye esslik etmekte, böylelikle iki kişilik bir oturma köşesi oluşturulmaktadır. Salonda yaygın olarak kullanılan bir diğer mobilya ise "zigon sehpa" olarak adlandırılan iç içe geçmeli servis sehpalarıdır. Gündelik yaşamda salonun bir köşesinde üzerinde dantel örtüyle bulunan bu takım misafir geldiğinde çıkartılarak misafirlere ayrı ayrı servis yapılma imkânı sağlamaktadır. 


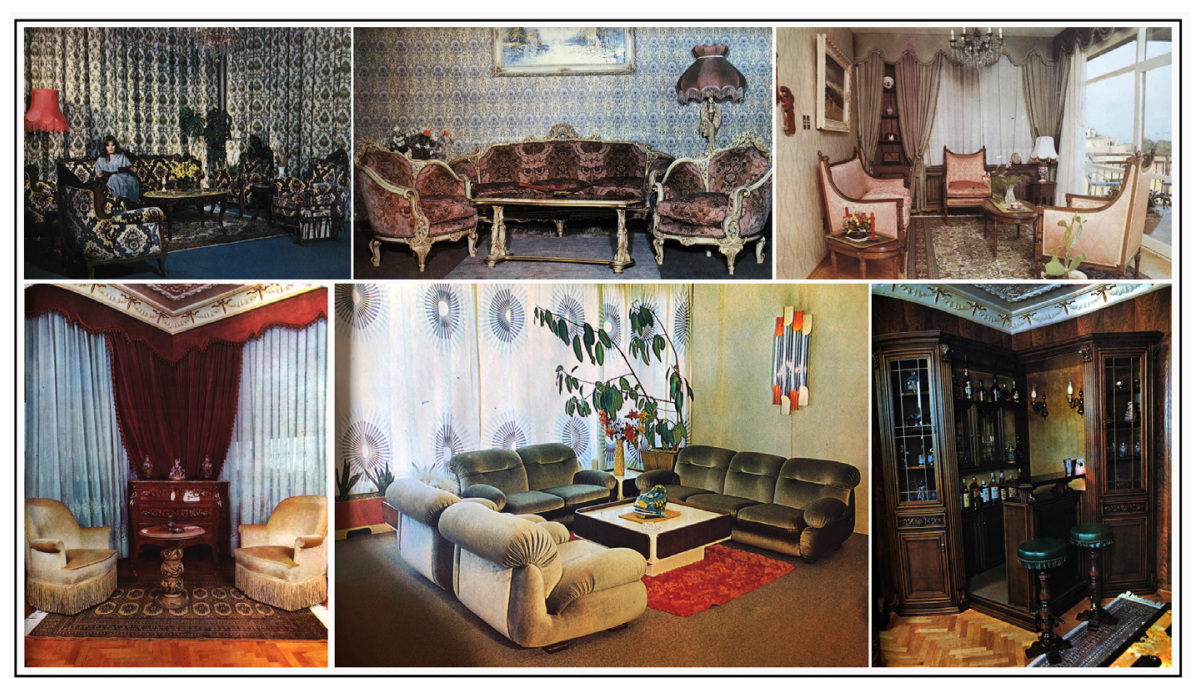

Görsel 3.Çisa mobilya koltuk takımı, Sayı 36, 1979. Avşar mobilya salon takımı, Sayı 43, 1980. XV. Lui stilinde salon takımı, Sayı 28, 1978. (Üstte)

Fiskos köşesi, Sayı 24, 1978. Kadife döşemeli takım, Sayı 17, 1978.ittalyan tarzında Amerikan barı, Sayı 24, 1978. (Altta)

Modern-rahat tarzdaki salonlarda takımlar genellikle iskeleti saklı, alçak ve genişoturumlu deri veya kadife kumaş kaplı koltuklardan oluşmaktadır. Klasik salonların aksine desenlerden arındııılmış kumaşların kullanıldığı saIonlarda genellikle toprak tonları kullanıımışır.

Alkollü içki eşliğinde sosyalleşme fikri, lüks evlerde "Amerikan bar" kavramıyla karşımıza çıkmaktadır. Amerikan bar, Amerika'nın ilerleme ve modernleşmeyi simgelemesiyle beraber konut kültüründe üst gelir gruplarının evlerine dahil ettiği bir düzenlemedir. Bu bar, ya mekânın bir bileșeni ya da bir mobilya parçasıdır. İki, taburelerle bir tezgâhtan oluşan ve alkollü içecekler sergilendiği bir mekân kısmıdır. İkincisi, șişelerin ve diğer ilgili aksesuarların saklandığı ya da sergilendiği daha büyük bir duvar ünitesi içinde bir dolap ya da kendi başına duran bir mobilyadır (Görsel 3) (Gürel, 2013:132).

Pencerelerde pirinç boru ya da kornişlere asılı uzun tül perdeler ve kadife kumaştan canlı renklerde veya yoğun desenlerde kalın ve ağır fon perdeleri kullanılmıştı. Aydınlatma elemanı olarak salonlarda genellikle kristal avizeler kullanılmıştır. Klasik üslubun hâkim olduğu salonlarda bu avizeler gösteriş ve statüyü temsil etmektedirler. Zeminlerde ahşap parke, rabıta²,

${ }^{2}$ Birbirine geçmeli tahtadan bir döşeme türü,Web: https://sozluk.gov.tr/ 12 Ağustos 2020'de alınmıştır. marley ${ }^{3}$ veya Vinylex adıyla özdeşleşen yer muşambaları; zemin üstünde ise yoğun motifli geleneksel desenlerde halılar veya duvardan duvara halıfleks kaplama kullanılmıstır. Duvar yüzeylerinde genellikle desenli duvar kağıtları veya parlak ve canlı renklerde yağlı boyalar tercih edilmiştir (Görsel 4).

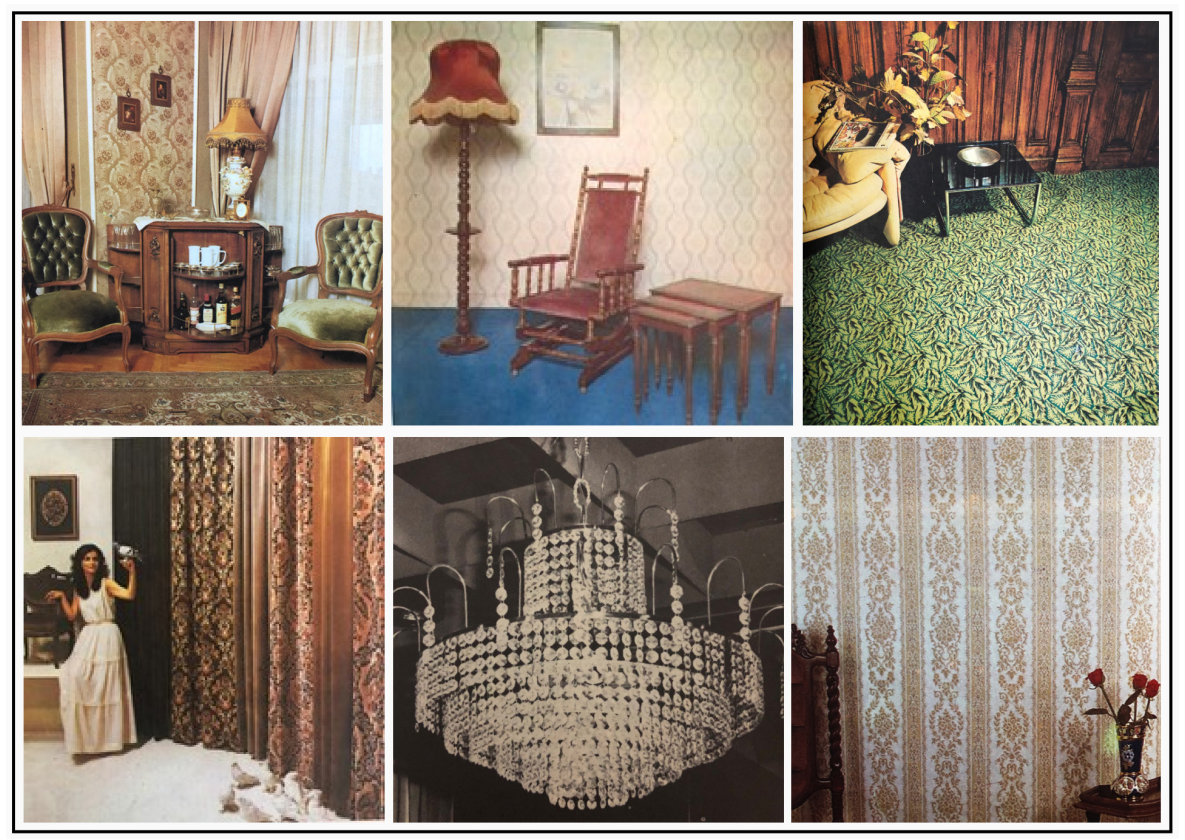

Görsel 4. Salonun bar bölümlü köşesi, Sayı 28, 1978.Çisa Mobilya ürünleri, Sayı 29, 1979. Yaprak desenli halıfleks, Sayı 16, 1977. (Üstte)

Kadife desenli fon perdeleri, Sayı 26, 1978. Kristal taşlı fiskiyeli avize, Sayı 17, 1978. Desenli duvar kâğıdı, Sayı 43, 1980. (Altta)

\subsection{Yemek Odası/ Bölümü}

Yemek odası kavramına geçmeden önce yemek masasının kültürümüze girişine değinmek gerekir. Osmanlıların 19. yüzyılda Batı ile olan ilişkilerinin artması sonucunda mutfak kültürümüz Avrupa kültüründen etkilenmeye başlamışır. Illk başlarda sofra adabında değişimler yaşanmış, sonrasında sininin yerini masa, minderin yerini ise sandalye almıştır (Güler, 2010). Tanzimat'tan sonra 1870 'li yılların saraylarında ve konaklarında yer sofrası terk edilmeye başlamış, yemekler masada yenmeye başlamıştır. Önceden

${ }^{3}$ Yapılarda döşeme gereci olarak kullanılan plastik madde, Web: https://sozluk.gov.tr/ 12 Ağustos 2020'de alınmıştır. 
sofrada yalnızca kasıık bulunurken artık çatal, bıçak ve su takımları da sofrada yerini almıştır. Bu değişim önce saray ve zengin konaklarında uygulanmış4 (Kut, 2005), Cumhuriyetin ilanından sonra modern yaşamın bir parçası olarak kent konutuna girmeye başlamıştır. Tüm dünyada olduğu gibi ülkemizde de sandalye ve sandalyeye oturmak batılılaşmanın simgesi haline gelmiştir (Demirarslan,2018:84). Apartmanlaşmanın arttı̆̆ı dönemde 1960 'lı yıllardan sonra gecekondular da dâhil, yemek masası konutların vazgeçilmez mobilyası olmuştur.

Konutlarda ayrı bir yemek odası yalnızca orta sınıftan ailelerin değil üst sınıftan ailelerin bile evinde çok yaygın kullanılan bir mekân değildir. Evlerde genellikle salonun bir köşesinde, bazen camlı bölme ile ayrılmış kısımda, tercihen kapıya ya da mutfağa yakın tarafta konumlanan yemek odası takımı ile bu ihtiyaç çözümlenmiştir.

Yemek odası takımları 6/8 kişilik yuvarlak veya kare masa, 6/8 sandalye ve camlı vitrin ve büfeden oluşmaktadır (Görsel 5). Üst gelir seviyesine hitap eden yemek odası takımları oymalı ve el işçiliği olan genellikle ceviz veya maundan üretilen mobilyalardır. 1970'lere doğru Formika firmasının adıyla anılan reçine emdirilmiş kâğıt kaplama malzeme veya lake boya ile üretilmiş, maliyeti masif takımlara göre daha uygun olan yemek odası takımları yaygınlaşmışıı.

Yemek odalarında da salon ile benzer olarak zeminlerinde ahşap rabıta veya marley, duvarlarında genellikle desenli duvar kâğıdı, pencerelerde boydan tül perdeler ve desenli fon perdeleri, zemin üstünde geleneksel desenlerde halılar kullanılmıştır.

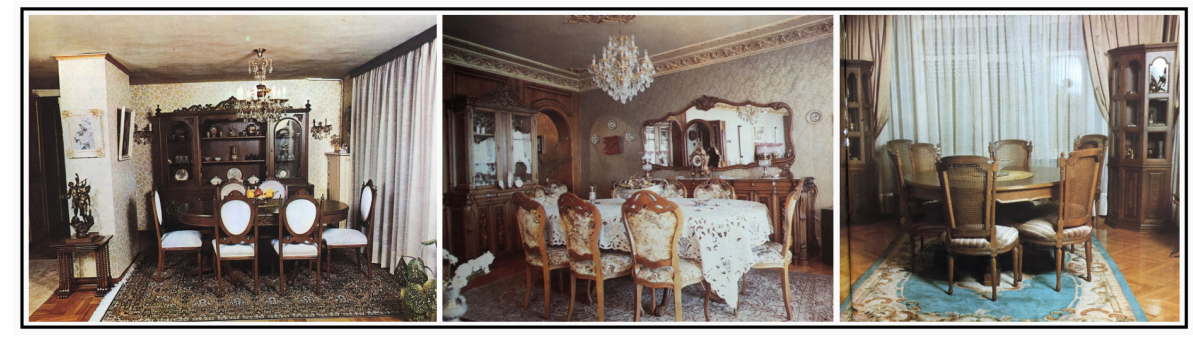

Görsel 5. Klasik İtalyan tarzında yemek odası takımı, Sayı 20, 1978. Kabataş’ta bir apartman dairesindeki yemek odası takımı, Sayı 64, 198I. Ceviz kaplama yemek odası takımı, Sayı 28, 1978.

Günay, K. (Kut, 2005). “Türklerde Beslenme Biçimi Dünü-Bugünü”, Çukurova Üniversitesi Türkolo| Araştırmaları Merkezi, http://turkoloji.cu.edu.tr/HALKBILIM/5 I.php, adresinden II Ağustos 2020'de alınmışıı.

\subsection{Oturma Odası}

Türklerde yerleşik hayata geçildikten sonra oluşan geleneksel konut tipinde günümüzdeki modern konutlarda olduğu gibi özelleşmiş mekanlar yerine birçok fonksiyonu içinde barındıran, aynı mekânın içinde yemek pişirme ve yeme, oturma, yatma, yıkanma, misafir ağırlama eylemlerinin gerçekleştirildiği odalar bulunmaktadır.

Türkler tarihsel süreç içinde yaşam biçimlerinde geçirdikleri değişimlere göre ise göçebe yaşam sürdükleri dönemde oturma setlerinde, yerleşik düzene geçtiklerinde geleneksel Türk Evi'nde divan, sedir, kerevetlerde, 19. yüzyılın ortalarından itibaren modern konutlara geçiş ile birlikte koltuk, kanepe, sandalye, tabure gibi oturma elemanlarında oturmuşlardır (Göker, 2009:168).

Modern konuta geçiş ile birlikte özelleşen oturma odaları, salondan ayr bir oda şeklinde olabileceği gibi salonun ortadan katlanır kapılar veya akordeon kapılar ile bölünmesiyle de oluşabilmektedir. Bu odalar konutun kullanıcılarının günlük yaşamlarını geçirdikleri salona göre daha sade ve geleneksel mobilyalarla döşenmiş bir mekândır (Görsel 6). Geleneksel konutun odalarındaki tefrişlerin çok yönlü kullanımı, sadeliği ve portatifliği bu dönemde modern konutun oturma odalarıla benzerlik göstermiştir. Oturma odalarında divan, kütüphaneli divan, sedir, somya, çek-yat, kanepe, koltuk, sandalye, yataklı kanepe, zigon sehpa, orta sehpa tipik oturma odası mobilyaları olarak karşımıza çıkmaktadır.

Modüler ve çok işlevli bir mobilya olan ve halk arasında "çek-yat" olarak isimlendirilen yataklı kanepeler ülkemize özgü bir mobilya türü olarak özellikle oturma odalarında yaygın bir şekilde kullanılmıştır (Özkaragöz: 1990; Demirarslan, 2018:84)

"Yaşama mekânı" da dediğimiz oturma odalarının düzenlemeleri etkileyen teknolojik gelişmelerin başında kuşkusuz televizyonun konuta girmesi gelmektedir. Televizyonun konumu mekânların kullanım şeklini, birbirleriyle olan ilişkilerini değiştirmiş; divanlar, kanepeler, koltuklar, sehpalar televizyonun konumuna göre tekrar düzenlenmistir. Televizyon genellikle odanın başköşesine yerleştirilmiştir. Televizyon aynı zamanda evlere aksesuarlarıyla birlikte girmiştir. Yıllarca evlerin büyük kısmında televizyonlar tekerlekli, altı kapaksız ve raflı bir sehpanın üzerinde yer almıştır (Tunç, 2001; Ceyhan, 2002:72)

Bu dönemde ve sonrasında da uzun yıllar kullanılacak bir başka oturma odası mobilyası ise televizyonu da içine alacak biçimde düzenlenen vitrinli 
dolaplardır (Görsel 6). Formika kaplı, vitrinli, açık ve kapalı rafları olan bu dolaplar oturma odasının veya salonun bir duvarını boydan boya kaplamaktadır. Bu dolapların ortasında televizyon yer almaktadır. Dantel örtü serili raflarda radyo, pikap, regülatör, ansiklopediler, eve hediye gelmiş ya da yurtiçi turistik gezilerde beğenilerek alınmış süs eşyaları, çerçeve içinde aile fotoğrafları bulunmaktadır. Vitrinin camlı bölümüne ise çay, su, kahve fincanı takımı, porselen yemek takımı vs. yerleştirilmiştir (Tunç, 2001; Ceyhan, 2002:72).

Oturma odasında zeminlerde ahşap rabıta veya marley, zemin üstüne duvardan duvara halıfleks kaplama veya geleneksel desenlerde halılar, duvarlarda desenli duvar kâğıdı veya tek renk yağlı boyalar, pencerelerde ise boydan tül perdeler ve dönemin simgesi haline gelen çiçek desenli kalın fon perdeleri kullanılmışıı.

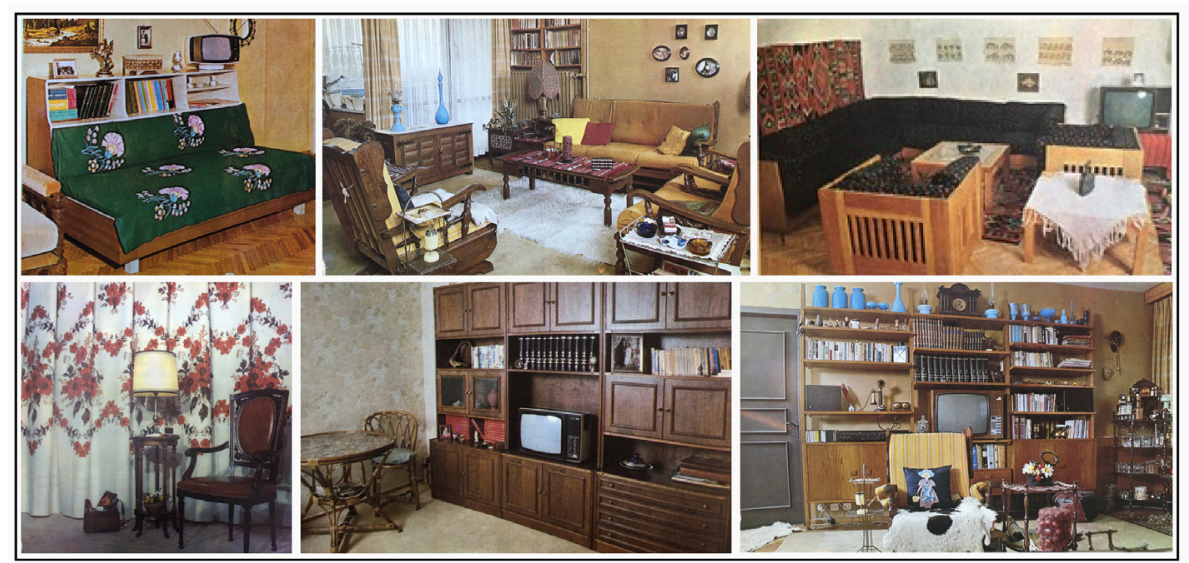

Görsel 6. Kütüphaneli divan, Sayı I7, 1978.Ataköy'de bir oturma odası, Sayı 22, 1978. Kemal Sunal'ın evinde oturma odası, Sayı 33, 1979. (Üstte)

Polyester dokuma perde, Sayı 22, 1978.Kütüphaneli vitrin, Sayı 30, 1979.Kütüphaneli vitrin, Sayı 22, 1978. (Altta)

\subsection{Ebeveyn Yatak Odası}

Konut içinde yatma eylemi; Osmanlı-i̇slam kültüründeki mahremiyet özelliğinden kaynaklı olarak en geç etkilenen işlev olmuştur. Bu sebeple batılı karyola konutlara en geç giren mobilya olmuştur. Karyola mobilyasının dışında yatak odalarına giren diğer batılı tarzdaki mobilyalar ise elbise dolapları, komodinler ve şifonyerlerdir. Geleneksel Osmanlı konutunda her odanın içinde yer alan sandık ve yüklükler zaman içinde yerini bu yeni mo- bilyalara bırakmış; bu mobilyaların kullanılmaya başlanmasıyla konutlarda yatak odası kavramı ortaya çıkmıştır (Demirarslan, 2006:51).1970'ler ile birlikte hazır yatak odası mobilyaları hayatımıza girmiștir. Kenarları boş, başları demirden karyolaların (Tunç, 2001:235) yerini yatak odası takımları almaya başlamışı. Bu dönemde yatak odalarında batı ile paralel olarak bir "ahşap çılgınlığı" baş göstermiş; yatak odaları ahşabın birçok farklı tonlarında klasik, yarı klasik veya modern tarzlarda takımlarla döşenmiştir. Bunun dışında Avrupa'da 1950'li yıllarda popülerlik kazanan yan yana ancak ayrı ikiz yataklar Türkiye'de de 1970'li yıllarda bir dönem popüler olmuştur (Görsel 7). Ayrı yatakların tercih sebebinin modernleşme ile artan bireyselleşmenin bir yansıması olduğu söylenebilir.

Klasik tarzda döşenmis adeta bir "saray odası" nı andıran yatak odalar özellikle 1980 'lerde; evlerde lüks yaşam ve gösterişe ilgi duyulan dönemde popüler olmuştur. Batı ile paralel olarak popülerlik kazanan bu yatak odaları Fransız ve Italyan yatak odası modellerinden etkilenilmiştir. Batılı tarzda üst gelir seviyesine hitap eden ceviz ağılıklı yatak odası takımları üç veya dört kapaklı gardırop, başucu komodinleri, başlıklı karyola, makyaj masası ve puftan oluşmaktadır. Başucu komodinlerinin üstünde genellikle abajurlar yer almaktadır.

1980 'lerin ortalarına doğru oymalı ve yoğun işlemeli yatak odalarının popülerliği modernizmin ülke gündemine girmesiyle birlikte azalmış, ahşabın daha sade olarak kullanıldığı; konforun ve kullanışın ön planda tutulduğu modeller popülerlik kazanmıştır. Bu dönemde hayata geçirilen uygulamalar, tüketim toplumuna dönüşme yolunda ilerleyen ülkede karmaşanın artmasına katkı sağlamıştır. Bu karmaşada yatak odalarında modern başlığı altında renk kullanımından malzeme kullanıma kadar birçok farklı tarz denenmis; 1990'lar bu denemelerin en yoğun yaşandığı yıllar olmustur. Ceviz ağırlıklı yatak odası takımlarının dışında seri üretime uygun olarak tasarlanan modeller formika veya lakedir. Yatak başucunda yer alan raflar ve derin dolaplar ise dönemin yatak odalarında sıklıkla karşımıza çıkmaktadır (Görsel7).

Yatak odasında duvarlar genellikle desenli duvar kâğıdı kaplı veya tek renk yağlı boyalı, zeminler ise ahşap rabıta, marley veya vinylex (muşamba)tir. Zemin üstüne duvardan duvara halıfleks kaplama veya küçük kilimler ile el dokuma halılar serilmistir. Pencerelerde boru ya da kornis üzerine takıl boydan tül perdeler ve desenli fon perdeleri kullanılmıştır (Bülbül Bahtiyar, 2019:62) 


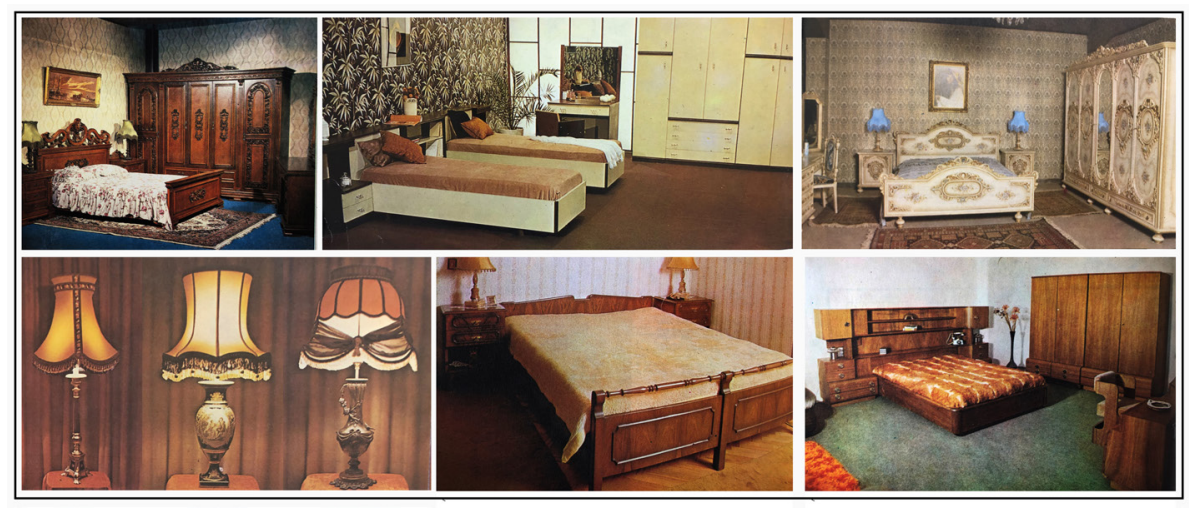

Görsel 7.Klasik yatak odası takımı, Sayı 34, 1979. İkiz yataklı yatak odası, Sayı 23, 1978.Lui Sez yatak odası takımı, Sayı 30, 1979. (Üstte)

Farklı stillerdeki abajurlar, Sayı 20, 1978. Ceviz kaplamalı mat yatak odası takımı, Sayı 16, 1977. Yatak başı raflı yatak odası takımı, Sayı II, 1977. (Altta)

\section{5. Çocuk Odası}

Çekirdek aile kavramının ön planda olduğu bu dönemde aile yapısı, konutların mekânsal oluşumlarında etkili olmuş, yeni biçimler kazandırmıștır. Ailede anne, baba ve çocuğun yeri netleşerek, bireyin mahremiyetine önem verilmiştir. Bunun sonucunda çocuk odaları gibi özel alanlar oluşmuştur. Aile içi hiyerarşi azalması, çocukların aile içinde birey olarak öne çıkarmış ve onlara özel mekânlar oluşturulmasını sağlamıştır. Çocuk odaları, çocukların yalnız yatak odaları değil, aynı zamanda çalışma ve oyun mekânlar haline gelmiştir. Böylece çocuklar zamanlarının büyük bir bölümünü kendi odalarında geçirmeye başlamışlardır (Özbay, 1996; Ceyhan, 2002:73).

Çocuk odası mobilyaları; karyola veya ranza, kapaklı dolaplar, başucu komodini ve çalışma masasıdır. Bu mobilyalarda genellikle çarpıcı, canlı renkler ya da pastel tonlar kullanılmıștır (Görsel 8). Çocuk sayısı fazla olan küçük evlerde çocukların yatması için ranzalar tercih edilmiştir. Bu ranzalar genellikle bükme boru ile yapılmıştır. Duvarlar canlı tonlarda boyalı veya çocuk odalarına özel desenli duvar kâğıdı ile kaplıdır. Zeminler ahşap rabıta, marley veya vinylex (muşamba)'tir. Zemin üstünde ise genellikle duvardan duvara halıfleks kaplama tercih edilmiştir.
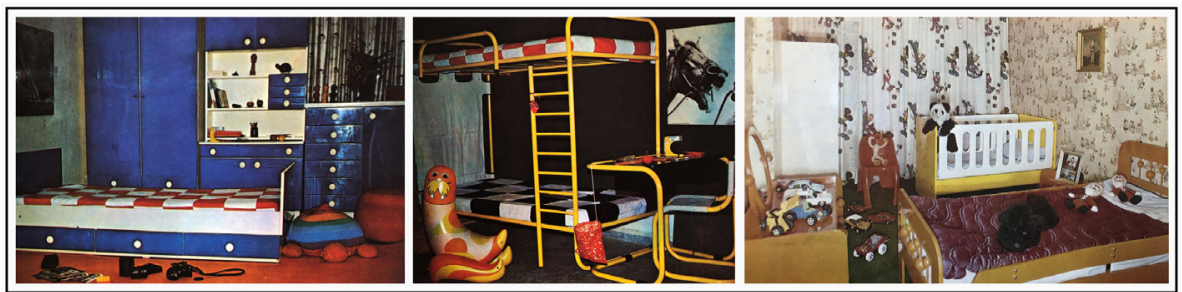

Görsel 8. Sunta üzerine parlak polyesterden imal edilmiş çocuk odası takımı, Sayı 24,1978. Bükme boru ranza ve çalışma masası, Sayı 24, 1978. Çocuk odası takımı, Sayı 22, 1978.

\subsection{Mutfak}

Türk evinde mutfak genellikle zemin katta ambar ve taşlık gibi birimlerle birlikte veya evin bahçesi içinde ayrı bir mekân olarak yer almaktayken geleneksel konutun yerini modern konutların almasıyla birlikte mutfaklar plan tipleri içine dahil edilerek değişime uğramıştır. Teknolojik gelişmeler sayesinde mutfaktaki eylemleri kolaylaştıran elektrikli aletlerin mutfaklara girmesive kadının çalışma hayatına dahil olmasıyla beraber aile ve toplum içindeki yerinin değişmesi mutfakların biçimlenmesinde etkili olmuştur (Pak, 1993).

Kentlerin kimliğini değiştiren mekânsal dönüşümler, özellikle 1970'li yıllara doğru kırsaldan kentlere gelen yoğun göçler sonucu artan konut ihtiyacın karşılamak üzere, az katlı eski yapıların yıkılarak yerine yapsatçı müteahhitlerin tasarımdan uzak, tek düze çok katlı yeni konutları yapmasıyla yaşanmıştır. Konut yapımına, ticari gözle bakıldığı için tasarımına ve üretim kalitesine yeterli önem verilmemiştir. Bunun sonucunda kent dokusunu yoğunlukla bitişik düzenle yapılan apartman mimarlığı oluşturmuştur. Bu dönemde mutfaklar apartman dairelerinde genellikle birden fazla dairenin küçük bir alana sığdırılmaya çalışılması veya bitişik nizamda ön cephede yaşama mekânının arka cephede yatak odalarının konumlanması sonucunda ışıklığa bakan kullanışsız ve oldukça küçük hacimli mekânlardır. Ancak dekorasyon dergilerinde mutfaklar mevcut mutfaklardan farklı olarak geniş hacimli ve oldukça donanımlıdır (Görsel 9).

$\mathrm{Bu}$ dönemde konuta yeni donatıların girdiği mekânlardan biri de mutfaklara buzdolabı ve aspiratörlü "fırınlı aygazlar" dahil olmuştur. Ancak küçük hacimli mutfaklarda buzdolabına yer ayrılamadığı için buzdolapları kullanım alanlarının dışına koyulmuş, üzerine el işi örtüler serilerek değeri vurgulanmış ve adeta bir mobilya ya da büfe gibi teşhir edilmiştir. 
Mutfaklarda tezgâhlar dökme mozaik, mermer ya da yerli üretim "20×20" fayanslar ile kaplıdır. Tezgâh ile üst dolaplar arasında kalan kısım genellikle fayans kaplıdır. Bu fayanslar kendinden desenlidir veya sonradan desenler yapıştırılmıştır. Mutfak tezgâhı ve duvarlarda kullanılan fayanslarda aynı desenin kullanıldığı örneklere de sıkça rastlanmaktadır. Mutfak dolaplar genellikle formikadan ya da renkli yapay ahşap levhalardan oluşmaktadır. Zeminlerde ise seramik veya karo mozaik kaplama kullanılmıştır.

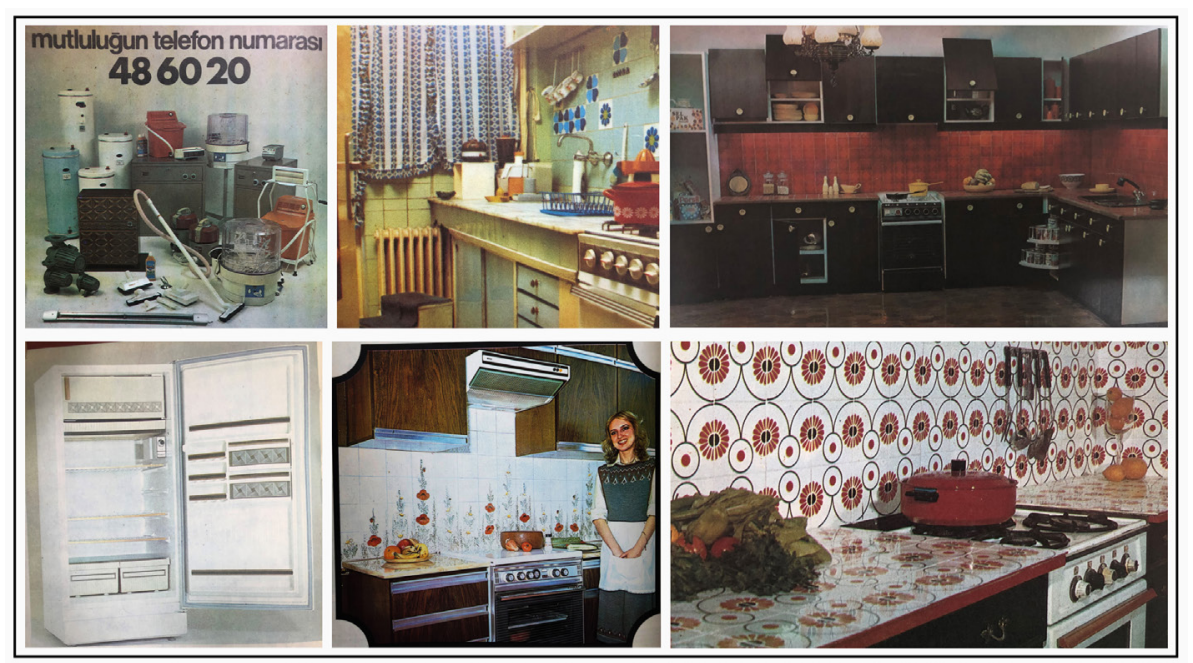

Görsel 9. Simtel marka elektrikli ev aletleri, Sayı 20, 1978.Dar mutfaklara bir örnek, Sayı 28, 1978. Geniş mutfaklara örnek, Sayı 34, 1979. (Üstte)

Arçelik yerli üretim buzdolabı, Sayı 2I, 1978. Mutfakta desenli fayanslar, Sayı 24, 1978. Duvarı ve tezgahı aynı desenli fayans kaplı mutfak, Sayı 35, 1979. (Altta)

\subsection{Banyo}

Türk geleneklerinde modern banyodan önce, temel hijyen ihtiyaçları alaturka tuvalet, hamam ve gusülhane ile giderilmiştir. Cumhuriyetin ilanıyla birlikte batılı yaşam tarzının özendirilmesi "modern banyo" kavramını beraberinde getirmistir. Modern banyo 20. yüzyılın ilk yarısı boyunca Avrupa'da ve Amerika'da sabitlenmiş vitrifiye elemanları ile sabit ve standart bir mekân haline gelirken, Türkiye'de de 1923 yılından sonra, yavaş da olsa yaygınlaşmaya başlamıştır (Aytaç ve Öğüt, 2015:6453).

Banyolar büyüklüklerine göre incelendiğinde, orta sınıf için sıkıştırılmış hücre tipi banyo çözümleri uygulanırkenüst ve üst-orta sınıf için ise genişletilmiş, nesnelerle donatılmış banyo çözümleri uygulanmıştır (Görsel 10) (Aytaç ve Öğüt, 2015). İkisinin de ortak elemanları; lavabo, klozet, küvet gibi vitrifiye elemanlarıdır. Ayrıca merkezi ısıtma sisteminin bulunmadığı evlerde suyu ısıtmak için termosifon veya şofben bulunmaktadır.

Avrupa'da banyoda beyazın egemen olduğu yılların ardından dekorasyonun öneminin artmasıyla birlikte renkli banyolar gündeme gelmiştir. Hâkim renk pembe olmuş, mavi ve yeşil banyolar pembeyi takip etmiştir (Aytaç ve Öğüt, 2015:6451). Türkiye'de ise 1970-80'li yıllarda renkli banyoların yanı sıra desenli karo mozaikler ve seramikler sıklıkla kullanılmıştır.

Banyolarda batılı tarzda "modern" elemanlardan biri olan klozetin yanı sıra, bir diğer "modern" eleman olan küvet, statünün ve Batılılaşmanın sembolü haline gelmiştir. Ancak, kültürel alışkanlıklar ve dini inanışlara göre durgun suda yıkanmayan Türk toplumu küveti yabancı olarak algılamıştır. Hamamdan bu yana alışılagelen akan suyla yıkanma alışkanlığına zıt bir nesne olarak küvet bir nevi duş teknesi olarak kullanılmıştır (Bektaş 1998; Gürel 2008; Aytaç ve Ögüt, 2015:6454) Illerleyen dönemlerde kullanımı kültürümüze daha elverişli olduğu için "oturmalı küvet"e geçilmiş, 1980'lerin sonuna kadar da küvet kullanımına yaygın bir şekilde devam edilmiştir (Aytaç ve Öğüt, 2015).

Batılılaşma ile apartmanlara ve evlere giren modern banyonun bir başka yabancı elemanı da "bide" olmuştur. Bide ilk olarak, cinsel ilişki sonrası genital bölgelerin temizlenmesi amaçlı Fransa'da kullanılmaya başlanmıştır (Rybczynski 1987; Aytaç ve Öğüt, 2015:6455). Türkiye'de ise, statünün ve modernizmin sembolü olarak algılanan ve klozet ile beraber set halinde satılan bide, banyolarda 1950-1970 arasında varlık gösterebilmiştir (Görsel 10) (Gürel 2008; Aytaç ve Öğüt, 2015:6455). Takip eden yıllarda hem banyoda çok yer kapladı $\breve{g}$ hem de klozetlere taharet musluğu eklendiği için bideye olan ilgi giderek azalmıștır. Bide, ayak yıkamayı kolaylaştırdığıgerekçesiyle çoğunlukla ayak yıkamak için kullanılmıştır (Aytaç ve Öğüt, 2015:6455).

1970'lerde yaygınlaşmaya başlayan çamaşır makinesi banyo içinde yer almayabaşlayan diğer bir elemandır. Apartman dairelerindeki küçük hacimli banyolarda çamaşır makinesi genellikle gece holüne, banyoya yakın yerlere yerleştirilmiştir 

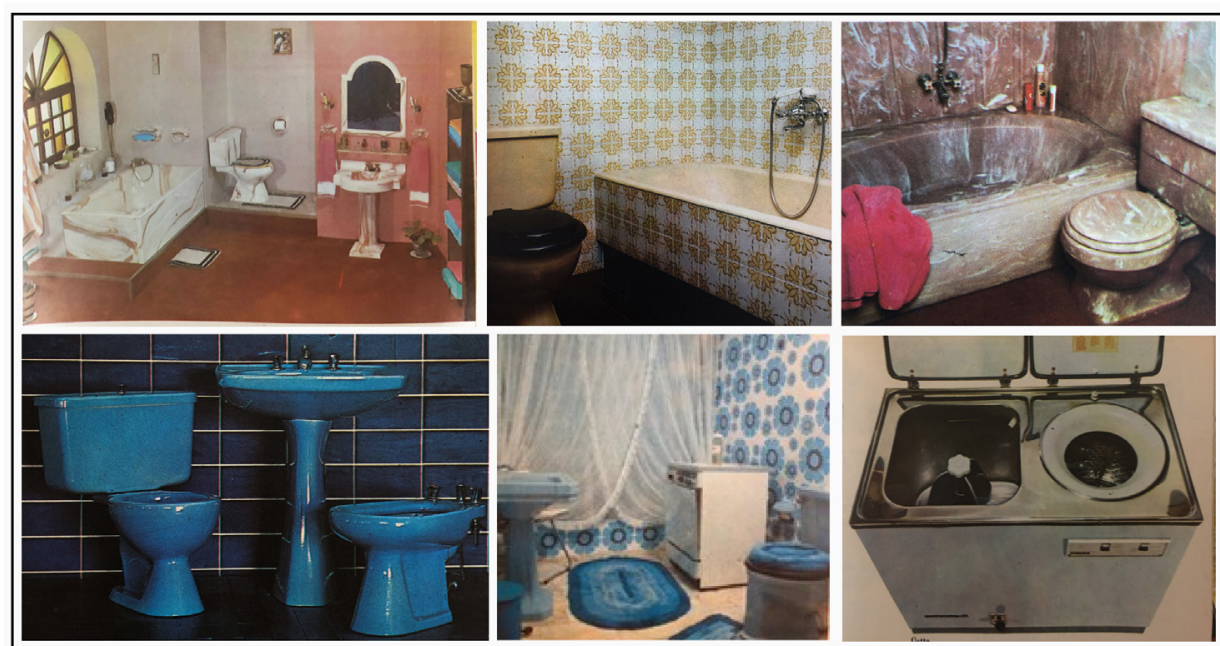

Görsel I0.Lavado marka "banyo odası", Sayı 22, 1978. (Üstte) Seramik ile kaplanmış bir banyo, Sayı II, 1977. (Üstte) Mermer banyo donatıları, Sayı 24, 1978.(Üstte)

Renkli, ayaklı lavabo, klozet ve bide, Sayı 24, 1978. (Altta) Çamaşır makinesinin yer aldığı banyo, Sayı 29, 1979. (Altta) Philips marka çamaşır makinesi, Sayı II, 1977.

$$
\text { (Altta) }
$$

\section{Değerlendirme}

Konutun mekanları kapsamında Ev Dekorasyon dergisi üzerinden desteklenerek yapılan değerlendirmeler sonucunda bu dönemde;

- Salonların “müze oda” olarak kullanıldı̆̆ı ve modern tarzın yanı sıra klasik tarzın daha ön planda olduğu; perde, döşemelik kumaş ve halı uyumuna dikkat edildiği,

- Yemek odalarının genellikle salonun bir bölümünde yer aldı̆̆ı, bu bölümde batılı yemek odası takımı olarak aynalı konsol, caml vitrin, yuvarlak veya kare masa ve sandalyelerin kullanıldığı ve genellikle klasik Batılı tarzın tercih edildiği bir mekân olduğu,

- Oturma odalarının salona göre daha sade ve kullanışlı bir mekân olduğu, televizyonun konuta dahil olması ile birlikte kendine bu odada vitrinli dolap ile yer bulduğu, çekyat ve divan gibi mobilyaların yer aldığı,

- Ebeveyn yatak odalarının takım mobilyalar ile döşendiği, ahşabın her tarzda ve modelde yoğun olarak kullanıldığı bunun yanı sıra
Fransız ve İtalyan klasik modellerinin tercih edildiği,

- Çocuk odalarında çarpıcı ve canlı renkler kullanıldığı, bükme boru ranza ve yatakların tercih edildiği, çocuk odalarına özel duvar kağıtlarının kullanıldı̆̆ı,

- Mutfakların apartmanlarda dar mekanlar olduğu, fırınlı ocak, buzdolabı ve küçük elektrikli aletlerin mutfaklara yeni yeni dahil edildiği, tezgahlarda ve duvarlarda desenli fayansların yoğun olarak kullanıldığı, formika kaplı dolapların tercih edildiği,

- Banyolarda batılı tarzda küvet, klozet ve bidelerin kullanıldığı, renkli vitrifiye elemanlarının tercih edildiği tespit edilmiştir (Tablo I).

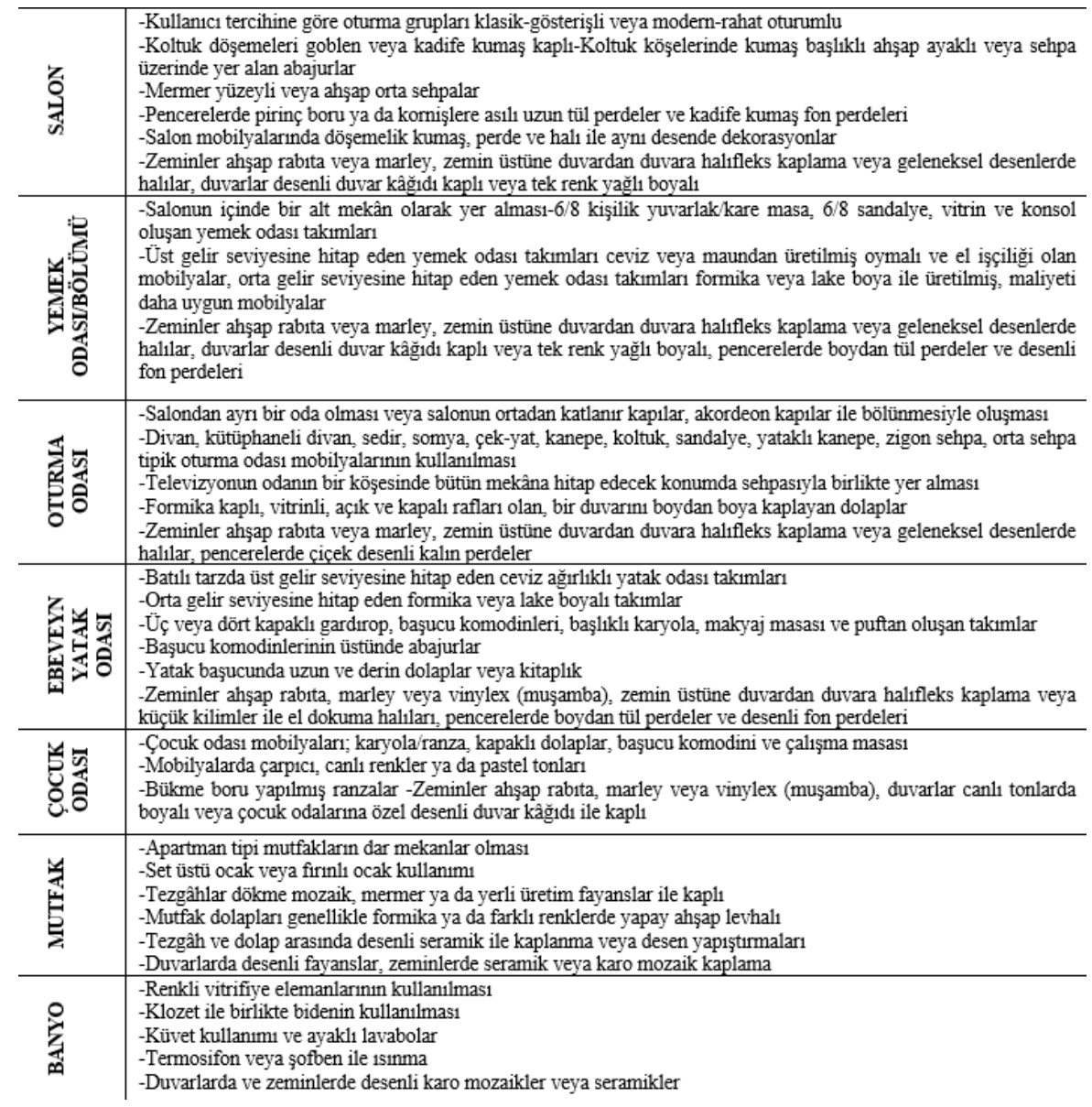

Tablo I. Ev Dekorasyon dergisi üzerinden dönemin konutlardaki iç mekânlar ve özellikleri 


\section{Sonuç}

Etkili kitle iletişim araçlarından biri olan yazılı basın; kapitalist düzenin etkisi ile toplumların tüketim alışkanlıklarına ve beğenilerine yön vermekte, ürünlerin kitlelere iletilip özendirilerek tüketimine teşvik etmektir. Günümüzde özellikle sosyal medya (facebook, instagram, twitter vb.) ve yazılı-görsel basın her alanda tüketim alışkanlıklarını yönlendiren araçlardandır. Ancak günümüzdeki gibi internet ve sosyal medya kullanımının olmadığı bir dönem olan 1970'li yıllarda yazılı basın, toplumsal beğenileri yönlendirmede etkili bir araç olmuştur. Yazılı basın dediğimiz gazeteler ve dergiler içinde bulunduğu dönem ve toplumsal koşullar ile doğrudan ilişkili metinler ve görseller içermekte ve bunlar vasıtası ile kitleleri yönlendirmektedir. Yazılı basının önemli bir parçası olan dergilerin içerisinde yer alan metinler ve görseller toplumdaki beğeniler, ekonomik ve kültürel değerler, sosyokültürel yapı, alışkanlıklar vs. gibi durumları okumak ve değerlendirmek adına önemli bir bilgi kaynağı oluşturmaktadır.

Bu kapsamda incelenen 1976-82 yılları arasında yayınlanmış Türkiye'nin ilk dekorasyon dergilerinden olan "Ev Dekorasyon" dergisi; 1970'li ve 1980'li yıllardaki konutların iç mekanları ve donatıları ile ilgili özelliklerin tespit edilebileceği bir veri olarak karşımıza çıkmıstır. Bunun yanı sıra dergi üzerinden incelenen dekorasyon anlayışlarının dönemin toplumsal, ekonomik ve kültürel değerleri ile paralellik gösterdiği görülmüştür.

1970 'li yıllardan sonra kentlere göçün de etkisi ile yaşanan kentleşme sonucu tüketim alışkanlıklarının değişmiş; statü göstergesi haline gelen mobilya kültürünün geleneksel Türk aile yaşamı ile örtüşmede zorluklar yaşadığı görülmüştür. Özellikle iç mekânda kullanılan mobilyaların Türk aile geleneksel yapısına uygunluğunun sorgulanmadan konutlara dahil edilmesi (küvet ve bide kullanımı, yemek masası kültürü gibi) ile deneme-yanılma şeklinde ilerleyen bir kabul görme süreci yaşanmıştır. Bu süreçte mobilyayı bir statü sembolü olarak gören kırsal/kentsel polemiği içerisinde klasik ve modern üslupların bir arada ilerlemiştir. Bunun yanı sıra yazılı basın ile özellikle sinema ve film yıldızı ünlü kişilerin ve tasarımcıların evleri, yaşam tarzları örnek olarak sunulmuş ve bu örnekler üzerinden toplumun tüketim alışkanlıkları yönlendirilmiştir. 


\section{Kaynakça}

Artıkoğlu, P. (2006).1950-1970 Arası Süreçte Sosyal Yaşam ve iç Mekânın Değişenleri Sanatta Yeterlik Tezi, Mimar Sinan Güzel Sanatlar Üniversitesi, Fen Bilimleri Enstitüsü, İstanbul.

Aytaç, A.ve Ögüt, Ș. T. (2015). “Türkiye’de Modern Banyonun Değişimi: Dergi Reklamları Üzerinden bir Değerlendirme”, Journal of Yasar University, I0(37), 6449-6464.

Bektaş, C. (1998). Bak Bak Desinler, İstanbul: Evrensel Basım Yayın.

Bülbül Bahtiyar, T. (2019). 1970-1990 Aralı̆̆ında Konut ve iç Mekân Özelliklerinin Kemal Sunal Filmleri Üzerinden Okunması, Yüksek Lisans Tezi,Necmettin Erbakan Üniversitesi, Fen Bilimleri Enstitüsü, Konya.

Canoğlu, S. (20I5). Türkiye'de Modern Mobilya Tasarımının Gelişimi: Öncü Mobilya Tasarımcılar Üzerine Bir Analiz, Yüksek Lisans Tezi, Anadolu Üniversitesi, Güzel Sanatlar Enstitüsü, Eskişehir.

Ceyhan, G. (2002).Türkiye'de Konut iç Mekanları ve Donatılarında Değişim ve Süreklilik, Yüksek Lisans Tezi, İstanbul Teknik Üniversitesi, Fen Bilimleri Enstitüsü, İstanbul.

Dağtaş, E. ve Dağtaş B. (2009). Tüketim Kültürü, Yaşam Tarzları, Boş Zamanlar ve Medya Üzerine Bir Literatür Taraması. E.Dağtaş ve B.Dağtaş. (Editörler) Medya Tüketim Kültürü ve Yaşam Tarzları. Ankara. Ütopya Yayınevi, s.27-75.

Dağtaş, B. (2003). Reklamı Okumak. Ankara: Ütopya Yayınevi.

Demirarslan, D. (2006). “Osmanlı'da Modernleşme/Batılılaşma Sürecinin iç Mekân Donanımına Etkileri”,Erdem Dergisi, I5(45-46-47),35-66.

Demirarslan, D. (2018). "Türk Yaşam Kültüründe Oturma Mobilyasının Değişimi ve Gelişimi”, Türk ve İslam Dünyası Sosyal Araştırmalar Dergisi, 6, 7I-86.

Dinçay, D. (2014). 1960-2010 Yılları Arasında İstanbul Kentli Konut İç Mekân Düzenlemelerini Türk Sineması Üzerinden Okumak, Doktora Tezi, İstanbul Teknik Üniversitesi, Fen Bilimleri Enstitüsü, İstanbul.

Durmuş, S. (2005). Türkiye’de Modern Mobilyanın Gelişimi. Yüksek Lisans Tezi, Marmara Universitesi Güzel Sanatlar Enstitüsü, Istanbul.

Featherstone, M. (2005). Postmodernizm ve Tüketim Kültürü(çev.M. Küçük)Ayrıntı

Yayınları.
Galbraith, K. J. (2009). Büyük Kriz 1929(çev. E. N. Akbaş) Pegasus Yayınları.

Göker, M. (2009). “Türklerde Oturma Elemanlarının Tarihsel Gelişim

Süreci”, ZeitschriftfürdieWelt der Türken/Journal of World of Turks, I(I), I63-I69.

Gönenç, A. Y. (2007). “Türkiye’de Dergiciliğin Tarihsel Gelişimi”, İstanbul Üniversitesi Iletişim Fakültesi Dergisi, 29, 63-78.

Güler, S. (20I0). “Türk Mutfak Kültürü ve Yeme İcme Alışkanlıkları”,Dumlupınar Üniversitesi Sosyal Bilimler Dergisi, 26(I),25-30.

Gürel, M. Ö. (2008). “Bathroom as a Modern Space”, Thejournal of Architecture, Sayıl3(3),215-233.

Gürel, M. Ö. (20I3). Bir Saygınlık Stratejisi Olarak Modern Mobilyanın Kullanımı. U. Şumnu (Derleyen). Erken Cumhuriyet Döneminde Mobilya. İstanbul. TMMOB İçmimarlar Odası, s. I2I-I39.

Güzer, A. (1999). “68'den 98'e Konutun ve Mimarın Kısa Öyküsü”, Cogito Dergisi, I8,242249.

Işık, N. ve Duman, E. (20I2). "Reel ve Finansal Göstergeler Açısından 1929 Ekonomik Buhranı ve 2008 Küresel Krizi: Karşılaştırmalı Bir Analiz”,Yönetim ve Ekonomi Dergisi, I9(2), 239-260

Kan Ülkü, G. (20I8). “Konutun Cinsiyeti”, Mimarlık Bilimleri ve Uygulamaları Dergisi, Sayı 3(2), 63-80.

Keleş, R. (1993).KentleşmePolitikası.Ankara: İmge Yayınevi.

Korkmaz, N. (2009). Türkiye'de Tüketim Kültürü ve Mekansal Ayrışma. Ankara: Ütopya Yayınevi.

Kurtoğlu, A. (1986). “Mobilya Stillerinin Tarihsel Gelişimi”, İstanbul Üniversitesi Orman Fakültesi Dergisi, 36(3), 70-9I.

Massey, A. (2008).Interior Design Since 1900.Londra: Thames\& Hudson.

Mutlu, N. (2009). Popüler Kadın Dergilerinde Kadın Temsili (Örnek Olay:

CosmopolitanDergisi), Yüksek Lisans Tezi,Selçuk Üniversitesi, Sosyal Bilimleri Enstitüsü, Konya.

Ödekan,A.(1997). Mimarlık ve Sanat Tarihi (1908-I980). S. Akşin (Editör). Türkiye Tarih 4: Çağdaş Türkiye 1908-1980. İstanbul.Cem Yayınevi, s. 369-453. 
Özakbaș, D. (20I4)."Cumhuriyet Dönemi Mimarlığının Siyasal, Ekonomik ve Sosyal Gelişmeler Paralelinde Modernleşme Süreci 1950-2000, Doktora Tezi, Mimar Sinan Güzel Sanatlar Üniversitesi Sosyal Bilimler Enstitüsü, İstanbul.

Özbay, F. (1996). “Evler, Kadınlar ve Ev Kadınları; Diğerlerinin Konut Sorunları”, Habitat 2 Ön Konferansı (s. 52-64), Ankara.

Özkaragöz, E. (1990).Kırsal Kesimden Kente Göçün Zaman Süreci İçinde Mekân Donatımına Etkileri, Yüksek Lisans Tezi, Mimar Sinan Güzel Sanatlar Üniversitesi, Fen Bilimleri Enstitüsü, İstanbul.

Pak, Z. (1993). Konut Mutfaklarının Analizi ve Minimum Mutfak Tasarımı, Yüksek Lisans Tezi, İstanbul Teknik Üniversitesi, Fen Bilimleri Enstitüsü, İstanbul.

Rybczynski, W. (1987).Home: A ShortHistory of an Idea. New York: PenguinBooks.

Saral Güneş, S. ve Kükrer Aydın, Ö. (2016). “Tüketim Kültürü Çerçevesinde Lüks Yaşam Tarzlarının Dekorasyon Dergilerindeki Reklamlarda Sunumu: Home Art Dekorasyon Dergisi Örneği”, Journal of Yasar University, I I (43). 220-239.

Şalgamcıoğlu, M.E.(20I3).isstanbul'da Çoklu Konut Gelişiminin Semantik ve Sentaktik Olarak Irdelenmesi: 1930-1980 Dönemi, Doktora Tezi, İstanbul Teknik Üniversitesi, Fen Bilimleri Enstitüsü, İstanbul.

Tunç,A.(200I).Bir Maniniz Yoksa Annemler Size Gelecek-70’li Yıllarda Hayatımız. İstanbul: YKY Yayınları.

Ultav, Z. T. Hasırcı D. Atmaca H. Borvalı S. (20I5)."Türk Modern Mobilyasının Peşinde”,Selçuk-Teknik Dergisi, I4(2), 480-497.

Yapar, A. (1999). Fransa ve Türkiye'de Dergicilik Olgusu ve Kadın Dergilerinin Karşılaştırılması, Doktora Tezi, İstanbul

\section{Internet Kaynakları}

Internet: Günay, K. (Kut, 2005). Türklerde Beslenme Biçimi Dünü-Bugünü. Çukurova Üniversitesi Türkoloji Araştırmaları Merkezi, Web: http://turkoloji.cu.edu.tr/HALKBILIM/5 I. php adresinden II Ağustos 2020'de alınmıştır.

Internet: Marley. Web: https://sozluk.gov.tr/ 12 Ağustos 2020'de alınmıştır. internet: Rabıta. Web: https://sozluk.gov.tr/ I2 Ağustos 2020’de alınmıștır.

\section{Görsel Kaynakları}

Ev Dekorasyon Dergisi, Temmuz 1977, Cilt 2, Sayı II, İstanbul. Ev Dekorasyon Dergisi, Aralık 1977, Cilt 3, Sayı 16, İstanbul. Ev Dekorasyon Dergisi, Ocak 1978, Cilt 3, Sayı 17, İstanbul. Ev Dekorasyon Dergisi, Nisan 1978, Cilt 4, Sayı 20, istanbul. Ev Dekorasyon Dergisi, Haziran 1978, Cilt 4, Sayı 22, i̇stanbul. Ev Dekorasyon Dergisi, Temmuz 1978, Cilt 4, Sayı 23, İstanbul. Ev Dekorasyon Dergisi, Ağustos 1978, Cilt 4, Sayı 24, İstanbul. Ev Dekorasyon Dergisi, Ekim 1978, Cilt 5, Sayı 26, ìstanbul. Ev Dekorasyon Dergisi, Aralık 1978, Cilt 5, Sayı 28, İstanbul. Ev Dekorasyon Dergisi, Ocak 1979, Cilt 5, Sayı 29, İstanbul. Ev Dekorasyon Dergisi, Şubat 1979, Cilt 5, Sayı 30, İstanbul. Ev Dekorasyon Dergisi, Mayıs 1979, Cilt 6, Sayı 33, İstanbul. Ev Dekorasyon Dergisi, Haziran 1979, Cilt 6, Sayı 34, i̇stanbul. Ev Dekorasyon Dergisi, Temmuz 1979, Cilt 6, Sayı 35, İstanbul. Ev Dekorasyon Dergisi, Ağustos 1979, Cilt 6, Sayı 36, İstanbul. Ev Dekorasyon Dergisi, Mart 1980, Cilt 8, Sayı 43, ìstanbul. 